\title{
The concentration of $\alpha$-tocopherol and ubiquinone in tissues of calves suffering from muscular dystrophy
}

\author{
By RITVA POUKKA \\ Department of Biochemistry, College of Veterinary Medicine, \\ Helsinki, Finland
}

(Received 30 August 1967-Accepted 3 January 1968)

\begin{abstract}
x. The concentration of $\alpha$-tocopherol was found to be low in the heart muscle, skeletal muscle and liver of young calves. In older animals it was significantly higher.

2. The $\alpha$-tocopherol concentration was lower in the heart muscle, skeletal muscle and liver of calves with nutritional muscular dystrophy than in healthy animals.

3. No difference in the concentration of ubiquinone-ro between healthy and diseased calves was found. A rather wide range of values was obtained for ubiquinone-ro in tissues.
\end{abstract}

\section{INTRODUCTION}

Deficiency of vitamin $\mathrm{E}$ is known to be one of the factors leading to muscular dystrophy in many animals. Besides vitamin $\mathrm{E}$, compounds of the coenzyme $Q$ family are known to be biologically active in some vitamin E-deficiency diseases (Dinning, Fitch, Shunk \& Folkers, I962; Smith, Bhagavan, Hill, Gaetani, Rama Rao, Crider, Johnson, Shunk, Wagner \& Folkers, I963; Wagner, Stopkie \& Folkers, 1964; Smith, Scholler, Moore, Farley \& Folkers, I966). The purpose of this investigation was to study the concentration of $\alpha$-tocopherol and ubiquinone-Io in tissues of healthy calves and calves suffering from enzootic muscular dystrophy.

\section{EXPERIMENTAL}

Reagents. Solvents used were of AR grade and were distilled before use. Ethanol was distilled over zinc dust and $\mathrm{KOH}$. $\alpha$-Tocopherol was purchased from Hoffman-La Roche Ltd, Basel, Switzerland and ubiquinone-ro from the Sigma Chemical Company, Saint Louis, USA.

Tissues. The animal tissue examined came from the province of Pohjanmaa where muscular dystrophy occurs enzootically and where the selenium content of the forage has been found to be low (Oksanen, 1965). The animals were killed at the slaughterhouse at Helsinki. The presence of muscular dystrophy was verified after the death of the animals, diagnoses being made macroscopically using as a criterion the characteristic greyish white symmetrically bilateral appearance of the dystrophic skeletal muscle. Only animals that showed extensive lesions of the skeletal muscle were included in the group of diseased animals. The samples were taken from the adductor muscles of the hind legs. At the same time as the samples were collected from the animals with muscular dystrophy, other samples were taken from healthy animals coming from the same area.

Calves. The calves were of the Finnish and Ayrshire breeds; they varied in age from I to 4 weeks. The slaughter weights of calves ranged from I4 to $29 \mathrm{~kg}$ and the weights of the hearts from $150 \mathrm{~g}$ to $393 \mathrm{~g}$. 
Little is known about the diets of the animals. The main diet of young calves in the Pohjanmaa province is whole milk and skim milk, although milk substitutes containing bone fat and tallow have come into use recently. However, in many farms of the area, the use of whole milk and skim milk for calves during the first weeks of life is more common.

Treatment of samples. Homogenization of tissues and extraction of $\alpha$-tocopherol and ubiquinone were performed by the method of Edwin, Diplock, Bunyan \& Green (1960). The volume of the acetone extract was reduced to one-third in a vacuum rotary evaporator, and the concentrated extract was made up to $50 \mathrm{ml}$. Of this solution, I $5 \mathrm{ml}$ (corresponding to $3 \mathrm{~g}$ of tissue) were transferred to a glass-stoppered centrifuge tube. The solvent was evaporated, and the lipid extract was saponified according to the method of Diplock, Green, Edwin \& Bunyan (I960). Immediately after the addition of the alkali, the tubes were flushed with nitrogen to exclude air. After saponification the tubes were cooled in an ice-water bath, and the unsaponifiable material was extracted rapidly with hexane, as described by Bieri (1967).

For determination of ubiquinone a sample of $\mathrm{I}-3 \mathrm{ml}$ of the acetone extract (corresponding to $0.2-0.6 \mathrm{~g}$ tissue) was applied directly without saponification to a thinlayer plate.

Thin-layer chromatography. Two-dimensional thin-layer chromatography (Bieri, 1967) was used for determination of vitamin E. For separation of ubiquinone, elution only in one direction with benzene-ethanol (99:x) was used. For identification of the compounds, corresponding standards were used. The $\alpha$-tocopherol spots were made visible by spraying the plates with a solution of the Emmerie-Engel $\left(\mathrm{FeCl}_{3}\right.$-dipyridyl) reagent, and ubiquinone was detected with leucomethylene blue, as described by Linn, Page, Wong, Gale, Shunk \& Folkers (I959).

The $\alpha$-tocopherol spot and a corresponding area from another plate (for blank determination) were removed from the plates directly into $1.5 \mathrm{ml} 0.02 \%$ bathophenanthroline in ethanol (Bieri, 1967 ) in a centrifuge tube. The suspensions were then mixed in a flask shaker and centrifuged. A sample of $\mathrm{I} \mathrm{ml}$ was taken for determination of absorbance. The spots of ubiquinone-Io were scraped off the plate directly into $3 \mathrm{ml}$ ethanol in a centrifuge tube. The suspensions were mixed in a flask shaker and centrifuged; the ethanol was pipetted off and the rinse repeated with another $3 \mathrm{ml}$ ethanol. The combined ethanol extracts were used for spectral analysis of ubiquinone-ro.

Spectrophotometric determinations. For determination of $\alpha$-tocopherol, a Unicam SP 600 spectrophotometer was used. After addition of $0.1 \mathrm{ml}$ of $0.03 \% \mathrm{FeCl}_{3}$ in ethanol the absorption at $534 \mathrm{~nm}$ was measured. For obtaining complete UV-absorption spectra of ubiquinone-1o in oxidized and reduced form, a Perkin-Elmer recording spectrophotometer (Model ${ }_{37}$ UV) was used. The quantitative determination of ubiquinone-10 was done with a Hitachi-Perkin-Elmer 139 UV-VIS spectrophotometer at $275 \mathrm{~nm}$ before and after addition of potassium borohydride. The $\Delta E_{1 \mathrm{~cm}}^{1 \%}$ value of 142 for ubiquinone-ro was used (Crane, Lester, Widmer \& Hatefi, 1959). 
RESULTS

Table I shows the values obtained for $\alpha$-tocopherol concentrations in tissues of healthy calves and calves suffering from muscular dystrophy. The concentration of $\alpha$-tocopherol was found to be low in the tissues of young calves. The concentration. was highest in the heart muscle and lowest in the skeletal muscle. In Table 2 the values of $\alpha$-tocopherol obtained for heifers and cows are presented. They were higher than those found for calves and the values for cows seemed to be much higher than those found for heifers.

Table. I. Concentration ( $\mu g / g$ wet weight) of $\alpha$-tocopherol in the heart muscle, skeletal muscle and liver of healthy calves and calves suffering from muscular dystrophy

(Mean values with their standard errors)

\begin{tabular}{|c|c|c|c|c|}
\hline \multirow[b]{2}{*}{ 'Tissue } & \multicolumn{2}{|c|}{ Healthy animals } & \multicolumn{2}{|c|}{ Diseased animals } \\
\hline & $\begin{array}{l}\text { No. of } \\
\text { animals }\end{array}$ & Concentration & $\begin{array}{l}\text { No. of } \\
\text { animals }\end{array}$ & Concentration \\
\hline Heart & 17 & I.94 $\pm 0.3 I$ & 7 & $0.34 \pm 0.16$ \\
\hline Skeletal muscle & 12 & $0.83 \pm 0.1 I$ & 7 & $0.3^{6} \pm 0.08$ \\
\hline Liver & I3 & $1.62 \pm 0.32$ & 7 & $0.81 \pm 0.31$ \\
\hline
\end{tabular}

Table 2. Concentration ( $\mu g / g$ wet weight) of $\alpha$-tocopherol in the heart muscle, skeletal muscle and liver of healthy heifers and cows

$\begin{array}{lcccc}\text { Tissue } & \overbrace{\begin{array}{c}\text { No. of } \\ \text { animals }\end{array}}^{\text {Concentration }} & \overbrace{\begin{array}{c}\text { No. of } \\ \text { animals }\end{array}}^{\text {Consentration }} & \text { Cons } \\ \text { Heart } & 2 & 3.62 & 3 & 7.54 \\ \text { Skeletal muscle } & 2 & 1 \cdot 10 & 2 & 3.82 \\ \text { Liver } & 2 & 2.09 & 2 & 4.41\end{array}$

Table 3 . Concentration ( $\mu \mathrm{g} / \mathrm{g}$ wet weight) of ubiquinone-10 in the heart muscle, skeletal muscle and liver of healthy calves and calves suffering from muscular dystrophy

\begin{tabular}{|c|c|c|c|c|c|c|}
\hline \multirow[b]{3}{*}{ Tissue } & \multicolumn{3}{|c|}{ Healthy animals } & \multicolumn{3}{|c|}{ Diseased animals } \\
\hline & \multirow{2}{*}{$\begin{array}{l}\text { No. of } \\
\text { animals }\end{array}$} & \multicolumn{2}{|c|}{ Concentration } & \multirow{2}{*}{$\begin{array}{c}\text { No. of } \\
\text { animals }\end{array}$} & \multicolumn{2}{|c|}{ Concentration } \\
\hline & & Mean & Range & & Mean & Range \\
\hline Heart & 7 & $138 \cdot 2$ & $102 \cdot I-185.0$ & 7 & II $7 \cdot 8$ & $73 \cdot 4-19 I \cdot 3$ \\
\hline keletal musc & cle 7 & 43.0 & $24 \cdot 1-64 \cdot 2$ & 7 & 447 & $19 \cdot 0-69 \cdot 6$ \\
\hline Liver & 7 & $30 \cdot 6$ & $20 \cdot 8-41 \cdot 5$ & 7 & $3 \mathrm{I} \cdot 0$ & $10 \cdot 4-57 \cdot 0$ \\
\hline
\end{tabular}

The concentration of $\alpha$-tocopherol in those tissues investigated was less in animals with dystrophy than in those of healthy animals. The difference was most pronounced in heart muscle, being significant at $0.1 \%$, but in skeletal muscle and liver also the difference was clear, being significant at $\mathrm{I} \%$.

In Table 3 the concentrations of ubiquinone-ro in the tissues of healthy animals and diseased animals are shown. No difference was found between these two groups of animals, and the range of values was very wide. 


\section{DISCUSSION}

The present investigation clearly demonstrates the low vitamin $E$ level in tissues of young calves. Green, Diplock, Bunyan \& Edwin (196r) found that the skeletal muscle of vitamin E-deficient rabbits had one of the lowest concentrations of $\alpha$-tocopherol ever observed by them, namely, $0.9 \mu \mathrm{g} / \mathrm{g}$ fresh weight. We found here that the skeletal muscle of calves with muscular dystrophy contained even smaller amounts of $\alpha$-tocopherol and that the $\alpha$-tocopherol level in tissues of healthy calves was also very low. The tissues of cows and heifers contained more $\alpha$-tocopherol.

The normal values for $\alpha$-tocopherol found in this investigation agreed very well with those found by Decker \& Hill (1957). For calves on a whole-milk diet their values for skeletal muscle ranged from 0.96 to $\mathrm{x} \cdot 70 \mu \mathrm{g} / \mathrm{g}$ fresh weight, whereas with a skimmilk diet the value was $0.52 \mu \mathrm{g} / \mathrm{g}$. Eaton, Teichman, Rousseau, Dicks, Grifo, Helmboldt, Jungherr \& Moore (1958) found somewhat higher values for the skeletal muscle than for the heart muscle of calves on a normal ration, $\mathrm{I} \cdot 4$ and $\mathrm{I} \cdot 2 \mu \mathrm{g} / \mathrm{g}$ on the wetweight basis, respectively. For livers they found $0.8 \mu \mathrm{g} / \mathrm{g}$. Blaxter, Brown $\&$ MacDonald (1953a) found significantly higher values for tissues of calves deprived of colostrum: $17.7 \mu \mathrm{g} / \mathrm{g}$ fresh tissue for heart, $7.8 \mu \mathrm{g} / \mathrm{g}$ for skeletal muscle, and $7.5 \mu \mathrm{g} / \mathrm{g}$ for liver.

Blaxter, Brown \& MacDonald (1953b) found no decrease in the $\alpha$-tocopherol level in calves with experimentally induced muscular dystrophy. On the contrary, they found higher amounts of $\alpha$-tocopherol in the degenerated areas of affected muscles than in healthy muscles of the same animals. In the present investigation, however, the $\alpha$-tocopherol level was found to be considerably lower in the tissues of dystrophic animals, compared to normal animals. This must be considered with the fact that it is known that the level of unsaturated fatty acids, especially that of linoleic and arachidonic acids, is increased in diseased animals (Poukka, 1966). This possibly indicates that, in the enzootic form of muscular dystrophy in calves, unsaturated fatty acids and vitamin $\mathrm{E}$ deficiency may play an important part. How these two factors are interrelated metabolically is not known. Green, Diplock, Bunyan, McHale \& Muthy (1967) pointed out that increasing tissue unsaturated fatty acids does not lead to a decrease in the concentration of tissue tocopherol, as happens in vitro, when unsaturated fatty acids are peroxidizing. Bernhard, Leisinger $\&$ Pedersen $\left(\mathrm{I}_{96}{ }_{3}\right)$ found that $\alpha$-tocopherol is necessary for metabolism of linoleic acid and that in vitamin $\mathrm{E}$ deficiency the content of arachidonic acid is increased.

According to Folkers' group, $\alpha$-tocopherol is possibly necessary for the metabolism of ubiquinone and therefore an antioxidant-deficient diet may lead to inadequate levels of ubiquinone in tissues (Wagner \& Folkers, 1963; Folkers, Smith \& Moore, I965; Smith et al. 1966).

Edwin et al. (196r) found that vitamin E-deficient rats have lower concentrations of ubiquinone in their tissues than vitamin E-supplemented animals. Green et al. (1961) found the same to be true in the vitamin E-deficient rabbit. According to Bird \& Szabo (1964), the ubiquinone levels are possibly some function of $\alpha$-tocopherol levels in the various tissues. In the present investigation, however, no decrease in 
ubiquinone content was found in animals with muscular dystrophy, whereas vitamin $\mathrm{E}$ deficiency was apparent. This is in agreement with the results of Morton \& Phillips (1959), Moore (1959), Phillips (1962) and Lee, Chiu \& Draper (1965). Lee et al. (1965) pointed to the multiple dietary factors which obviously influence the ubiquinone level. Bieri (1966) is of the opinion that because of the complexity of the control of ubiquinone metabolism, little information about the relationship between vitamin $\mathrm{E}$ and ubiquinone can be expected to result from experimentation with the whole animal.

\section{REFERENCES}

Bernhard, K., Leisinger, S. \& Pederson, W. (1963). Helv. chim. Acta 46, 1767.

Bieri, J. G. (1966). Vitams Horm. 24, 587.

Bieri, J. G. (1967). In Chromatographic Analysis of Lipids, ch. 9. [G. V. Marinetti, editor.] New York: Marcel Dekker, Inc.

Bird, J. W. C. \& Szabo, N. A. B. (1964). Proc. Soc. exp. Biol. Med. I17, 345.

Blaxter, K. L., Brown, F. \& MacDonald, A. M. (1953a). Br. F. Nutr. 7, 105.

Blaxter, K. L., Brown, F. \& MacDonald, A. M. (r953b). Br. F. Nutr. 7, 287.

Crane, F. L., Lester, R. L., Widmer, C. \& Hatef, Y. (x959). Biochim. biophys. Acta 32, 73.

Decker, P. \& Hill, H. (1957). Dt. tierärztl. Wschr. 64, 396.

Dinning, J. S., Fitch, C. D., Shunk, C. H. \& Folkers, K. (1962). F. Am. chem. Soc. 84, 2007.

Diplock, A. T., Green, J., Edwin, E. E. \& Bunyan, J. (I960). Biochem. F. 76, 563.

Eaton, H. D., Teichman, R., Rousseau, J. E. Jr, Dicks, M. W., Grifo, A. P. Jr, Helmboldt, C. F., Jungherr, E. L. \& Moore, L. A. (1958). F. Anim. Sci. 17, 804.

Edwin, E. E., Diplock, A. T., Bunyan, J. \& Green, J. (1960). Biochem. F. 75, $45 \circ$.

Edwin, E. E., Diplock, A. T., Bunyan, J. \& Green, J. (I96I). Biochem. F. 79, $9 \mathrm{I}$.

Folkers, K., Smith, J. L. \& Moore, H. W. (r965). Fedn Proc. Fedn Am. Socs exp. Biol. $24,79$.

Green, J., Diplock, A. T., Bunyan, J. \& Edwin, E. E. (196r). Biochem. F. 79, 108.

Green, J., Diplock, A. T., Bunyan, J., McHale, D. \& Muthy, I. R. (r967). Br. J. Nutr. 2 I, 69.

Lee, D. J., Chiu, M. \& Draper, H. H. (1965). Nature, Lond. 205, 288.

Linn, B. O., Page, A. C. Jr, Wong, E. L., Gale, P. H., Shunk, C. H. \& Folkers, K. (1959). J. Am. Oil Chem. Soc. 8r, 4007.

Moore, T. (1959). Nature, Lond. $\mathbf{8 4}, 607$.

Morton, R. A. \& Phillips, W. E. J. (1959). Biochem. F. 73, 427.

Oksanen, H. E. (1965). Acta vet scand. 6, Suppl. 2.

Phillips, W. E. J. ( (962). Can. F. Biochem. Physiol. 40, 1347.

Poukka, R. (1966). Br. F. Nutr. 20, 245.

Smith, J. L., Bhagavan, H. N., Hill, R. B., Gaetani, S., Rama Rao, P. B. R., Crider, Q. E., Johnson, B. C., Shunk, C. H., Wagner, A. F. \& Folkers, K. (r963). Archs Biochem. Biophys. ror, 388.

Smith, J. L., Scholler, J., Moore, H. W., Farley, T. M. \& Folkers, K. (1 966). Archs Biochem. Biophys. I16, 129 .

Wagner, A. F. \& Folkers, K. (1963). Perspect. Biol. Med. 6, 347.

Wagner, A. F., Stopkie, R. J. \& Folkers, K. (1964). Archs Biochem. Biophys. 107, I84. 